\title{
The Challenge of Human Rights for Peace Research
}

\author{
Andreas H. Hvidsten ${ }^{1} \&$ Kjersti Skarstad ${ }^{2}$
}

\begin{abstract}
Human rights law posits a close, almost self-evident, relation between human rights and peace. Peace researchers, however, see this relation as an unsettled empirical question. In this essay, we consider the peace researchers' (implicit) critique of human rights law. We argue that seeing the relation between human rights and peace as an empirical question rests on a largely unexamined conceptual separation of justice and peace. Re-investigating this conceptual relation reveals two positions that have different implications for human rights and peace: (1) a 'negative' understanding of peace as stability, and (2) a 'positive' understanding of peace as a working social contract. On the negative understanding, human rights may or may not be instrumentally effective in maintaining stability, which is rightly seen as an empirical question. On the positive understanding of peace, on the other hand, human rights are potentially conceptually related to peace, and the relation cannot be reduced to an empirical question. We argue that (2) is a better understanding of peace - at least the kind of peace envisioned in human rights philosophy - and provides a potential bridge between human rights scholarship and peace research.
\end{abstract}

Key words: human rights, peace research, negative peace, positive peace, justice, stability

Word count: 10750 (including abstract, references and endnotes)

\footnotetext{
${ }^{1}$ Department of Political Science, University of Oslo. E-mail: a.h.hvidsten@ stv.uio.no.

${ }^{2}$ Department of Political Science, University of Oslo. E-mail: kjersti.skarstad@stv.uio.no.
} 


\section{Introduction}

In human rights philosophy and human rights law, a close relation between human rights and peace is considered almost self-evident (Tuck 1999). This article of faith is explicitly stated in the preamble of the Universal Declaration of Human Rights, which claims that the 'inherent dignity and of the equal and inalienable rights of all members of the human family is the foundation of [...] peace in the world' (UN General Assembly $1948 .{ }^{1}$ Contemporary peace research, ${ }^{2}$ however, treats the relation between human rights and peace as less obvious (Collier \& Hoeffler 2004; Skarstad \& Strand 2016).

This difference in attitude is largely an epistemological difference. For peace researchers, the relation between human rights and peace cannot be settled by philosophical reasoning or simply decreed in law; whether there really is a relation between human rights and peace is an (as of yet unsettled) empirical question. This approach to human rights and peace flows from a particular commitment to what it means to treat something scientifically, which is to subject claims to empirical testing. So far, the empirical tests of the (hypothesized) relation between human rights and peace have been inconclusive. ${ }^{3}$

If peace researchers are correct in their way of approaching the issue of human rights and peace, then much of human rights philosophy and law is built on largely unverified empirical claims. This is not to be taken lightly. The relation between human rights and peace is a big part of the legitimacy of human rights law (Forsythe 1993; Glendon 2002; Nickel 2007; Steiner et al. 2008). Moreover, the intersection of human rights and peace forms the centre of several debates within the UN system, such as the recent controversy within the UN Human Rights Council on the 'right to 
peace', and the debate on the role of human rights protection in UN peacekeeping operations (Bailliet \& Larsen 2013; Bailliet 2014). ${ }^{4}$

Thus, the relation between human rights and peace is not just of academic interest, but an important political question. If peace research can offer answers to the controversies surrounding human rights and peace-or at least the prospect of answering them-human rights scholars and political practitioners should listen. However, first we should establish whether peace researchers have asked the question in the right way. Is the relation between human rights and peace an empirical, a normative or a conceptual question? In this essay, we make the case that it is all three things at once, and that this creates challenges for peace researchers aiming to incorporate human rights into their research. The aim of this essay is both to explore this complexity and its implications, and to suggest a path through this epistemological, analytical and political maze.

The arguably most common approach in peace research is to treat the relation between human rights and peace as a purely empirical question. This approach, we point out, builds on an (usually unexamined) assumption that human rights and peace can be conceptually separated. Furthermore, this conceptual separation-rooted in a negative understanding of peace (see below) - is, we contend, problematic, both analytically and politically. Instead of approaching the relation of human rights and peace as a purely empirical question, we argue that an empirical study of this relation should start from an appreciation of the conceptual relation between human rights and peace, such as we find in the 'social contract', positive understanding of peace advocated by some peace researchers. 
On a social contract understanding, peace consists of a fundamental societal framework that resolves conflicts in a non-violent manner. Human rights, we argue, are a good candidate for such a framework. Our preference for social contract approach to peace and human rights is based on normative and conceptual considerations concerning what kind of 'peace' is worth pursuing. However, this does not mean that the issue of human rights and peace is reduced to a purely conceptual and normative question. There are important empirical questions to be resolved related to how to make a human rights approach to peace work in practice. These challenges fuel a body of interesting empirical work connected the role of human rights, and justice considerations more broadly, in peace building (e.g. Evans 2016; Gready and Robins 2014; Millar and Lecy 2016; for critical views, see e.g. Anonymous 1996; Snyder and Vinjamuri 2006).

This essay raises issues beyond the topic of human rights and peace. It is also an explication and defence of the philosophical underpinnings - or at least one possible, human rights-based philosophical underpinning - of the positive peace tradition, contrasted with it is main alternative. We found that we could not properly engage with the question of human rights and peace without also raising these larger conceptual, political and epistemological background issues. This is in itself a big part of what we wish to communicate: that taking human rights seriously has more fundamental implications for the study of peace than one might think. ${ }^{5}$

Consider the conceptual challenge first. The prevailing orthodoxy in peace research is to define peace 'negatively' ${ }^{6}$ as the absence of organized, armed, political conflict - a definition that, in effect, equates peace with stability. However, if peace 
means merely stability, then human rights, which are primarily concerned with justice, claims normative priority over (negative) peace. Thus, we would argue, the 'peace' implied in human rights philosophy cannot reasonably be reduced to 'stability'. Accordingly, peace researchers who are serious about investigating the claims contained in human rights law and philosophy must first and foremost engage in fundamental conceptual reflection. Specifically, we make the case that including human rights in peace research means transitioning to a positive concept of peace.

Secondly, a more considerate engagement with human rights can also put some perspective on the current mismatch between much of the scholarly practice of peace research, based on a negative understanding of peace, and the political practice of peacebuilding, based on a more positive understanding of peace. One of the core concerns of UN peacebuilding programs, for instance, is 'restoring social contracts between the state and the people'. ${ }^{7}$ If a working social contract is a crucial feature of the state of affairs we call 'peace', then promoting peace and promoting justice are two sides of the same coin - in which case the struggle for human rights might be, ipso facto, a struggle for peace.

Finally, in addition to conceptual innovation and a bridge to political practice, human rights could help peace research establish a firmer normative basis for its empirical work-just as peace research could conceivably add a new empirical dimension to human rights scholarship. Connecting the project of establishing stability - the traditional concern of (negative) peace research - to the project of establishing justice - the traditional concern of human rights scholars-could be beneficial to both traditions. The stability seekers would have a new conceptual- 
normative tool set for distinguishing between 'good' and 'bad' stability, something which peace research currently struggles to do (see section 3 ). The justice seekers would have an empirical check on their ambitions, and a constant reminder that the pursuit of ideals must be mediated by facts on the ground and political feasibility.

We see a great potential in a closer connection between peace research and human rights scholarship, and the main aim of this essay to contribute to such a connection by clearing up certain conceptual stumbling blocks. The essay is structured as follows. In section 2, we clarify certain important conceptual commitments we are making that form the basis of our argument. Section 3 is a critique of the most common way of investigating the relation between human rights and peace in peace research. Section 4 contains the constructive part of our argument where we, in three sub-sections, consider the possibility of establishing common ground between peace research and human rights scholarship through a positive concept of peace.

\section{Order, justice and human rights}

The concepts of 'order' and 'justice' play important roles in our argument. As, of course, do the concept of 'human rights'. We begin by clarifying our understanding of these concepts and how they are connected. The concept of 'peace' will be discussed throughout the essay, and is only briefly touched upon in this section.

We are primarily interested in human rights as a standard of justice (as in Donnelly 2013) capable of conferring political legitimacy on, inter alia, political acts, movements and political orders (see below). Broadly speaking, a standard of justice is a measuring rod for whether and to what degree any particular act, movement, or society more generally, merits the designation 'just' in a broad sense of the word and 
as such deserves our political allegiance. A standard of justice, then, has a critical relation to any particular empirical phenomenon - a person, an act, a state - to which it applies, meaning that it provides a positive or negative political judgement (or a bit of both) on the phenomenon in question, justifying political responses ranging from resistance to support.

A standard of justice, in short, is a political ideal. Human rights are a particularly important (although not the only) component of the modern political ideal — the modern idea of the just society — that rose to prominence during and after the Enlightenment (the historical roots of this transformation, however, run much deeper, see e.g. Siedentop 2014). In the Western world at least, there is now widespread agreement among most political ideologies and philosophies on a minimal conception of human rights (Donnelly 2007; Nickel 2007). Human rights are part of what John Rawls has called non-negotiable "constitutional essentials", which include

[e]qual basic rights and liberties of citizenship that legislative majorities are to respect: such as the right to vote and to participate in politics, liberty of conscience, freedom of thought and of association, as well as the protections of the rule of law (Rawls 2005: 227).

We should make two caveats. First, the consensus on human rights is not universal. Competing concepts of justice, representing alternative boundaries of political legitimacy, such as political Islamism exist and seem to thrive in certain parts of the world (Euben and Zaman 2009). Second, although a good case can be made for the importance of justice — including human rights-based justice - also on the international 
level (Henkin 1995; Reus-Smit 2011; Simmons 2009), the role of standards of justice in international affairs is a particularly contested issue. ${ }^{8}$

By 'order' we refer to the basic organizing principles, whether explicitly codified in law and institutions or implicitly acted out in practice, that gives structure to social and political life-local, national or international (Bull 2002: 6-7). This order does not have to be fair, unchallenged or agreeable to all parties, nor brought about by design. However, some kind of order is always in place. Even international politics, which might be the most unsettled of all social orders (Seth 2013: 28), is not without “constitutional structure" (Reus-Smit 1997); there is always some background in place that "define both the rules of the game and what the pieces are" (Buzan 2014: 31). (The reader should note that our use of the term 'order' is not equivalent to 'stability', which is a property any given order might or might not enjoy).

Our argument rests crucially on a duality in the relation between human rights and order. Firstly, human rights (qua standard of justice) stand in a normative relation to any given order, providing an ideal for judging this order as more or less legitimate or illegitimate. Secondly, human rights, as they are more concretely spelled out in the Universal Declaration and elsewhere, are an explicit set of basic rules - a candidate for order. Thus, human rights (qua set of basic rules) have a constitutive relation to a certain kind of order. If human rights are respected, i.e. if the basic rules of human rights are adhered to, a human rights-based order is brought into being.

Human rights, in short, stand in both a normative and a constitutive relation to order. Let us dwell for a moment on the complexity of this dual relation, which is particularly intricate in the case of the constitutive aspect of the relation. How - that is, 
through what causal mechanism-can human rights constitute a certain order?

Obviously, it is not enough to endorse human rights in theory (just as calling itself a 'democratic republic' does not make North Korea a democratic republic). For a human-rights order to be a reality, human rights must be respected and acted upon in practice, by the government and people more generally, not simply declared.

Thus, the causal agents that bring a human-rights based order to life are, in the last instance, people - either through institutions or as private individuals-who through their social practices uphold a certain liberal political community centred on a fundamental respect for individual autonomy. Of course, such a community is not always already present, in which case realizing human rights might be politically undermining to the established order, even revolutionary. This was certainly the case when the radical idea of individual rights first appeared on the scene in Europe, as Christian Reus-Smit relates:

[i]n their twilight years, the Holy Roman Empire, the Spanish Empire, and Europe's nineteenth- and twentieth-century empires all suffered severe crises of legitimacy. Political systems experience such crises when support among those subjected to their rule collapses [...]. [...]. New, distinctly modern ideas about individual rights took root in each context, and as they spread, were interpreted, reconstituted and embraced as legitimate, subject peoples re-imagined themselves as political agents, developed new political interests in the recognition and protection of their rights, challenged established regimes and entitlements, and sought institutional change (Reus-Smit 2013: 4).

Interestingly for our discussing of the relation between human rights and peace, the process Reus-Smit is describing was not necessarily 'peaceful'. In some instances, most notably the French revolution, the struggle for individual rights was (part of) a 
violent struggle. At first blush, then, it would seem that human rights has an ambiguous relation to peace: 'peace' presumably involves stability and human rights (qua standard of justice) can legitimize rebellion as well as obedience to any existing political order, and as such (potentially) cause both stability and instability.

Thus, when investigating the relation between human rights and peace, it matters deeply how one thinks about the concept of 'peace'-particularly whether one defines peace as equivalent to stability as such ('negative peace') or as stability underpinned by justice ('positive peace'). In the next two sections, we explore this complexity and show how different definitions of peace, far from being merely a pragmatic research issue of operationalization, sets up different epistemological and political backgrounds for incorporating human rights into peace research.

\section{Negative peace: peace and human rights as an empirical question}

In this section, we consider how the issue of human rights and peace presents itself on a negative understanding of peace, which is arguably the most common understanding of peace in contemporary peace research (Gleditsch et al. 2014). A negative definition defines something in terms of what it is not. The most common negative definition of peace defines peace as the absence of an armed political conflict between organized actors, in which a certain threshold number of battle deaths has occurred (Gledistch et al. 2002; Themnér \& Wallensteen 2012). We refer to peace research based on a negative understanding of peace as 'negative peace research'.

The first thing to note is that a negative definition of peace conceptually decouples peace from concerns of justice and legitimacy - and therefore from human rights. Not to say that peace and justice cannot co-exist on this understanding, but if 
the essence of peace is absence of armed conflict then it is certainly possible to have peace without justice. Contemporary North Korea, for instance, is a peaceful society on a purely negative definition of peace, even if it might not be a just society or a legitimate regime. Another way to put this is that the essence of negative peace is not justice, but stability.

However, negative peace researchers have not removed human rights from their analyses even if they have removed justice from the concept of peace itself. Indeed, in the period 1964-2012 the words 'human rights' are mentioned almost as often as 'armed conflict' in abstracts and titles in Journal of Peace Research (Gleditsch et al. 2014: 152). Instead of seeing human rights as (potentially) constitutive of peace, however, they have been given explanatory role: '[a]rticles on cooperation and other forms of peaceful interaction increasingly emphasize how these serve to reduce the probability of armed conflict' (Gleditsch et al. 2014: 152). We will now briefly explicate the causal logic behind this relation.

The primary explanatory task in negative peace research is to account for the motivation and opportunity for actors to take up arms against each other (see e.g. Fearon \& Laitin 2003; Collier \& Hoeffler 2004). Lack of respect for human rights is a potential motivation for rebellion. The famous statement in the preamble to the Universal Declaration of Human Rights (1948) that reads 'it is essential, if man is not to be compelled to have recourse, as a last resort, to rebellion against tyranny and oppression, that human rights should be protected by the rule of law' can be interpreted as an empirical hypothesis on what motivates men and women to rebel 
(Forsythe 1993). As such, this claim can be empirically tested: perhaps human rights abuses are not an important motivation for taking up arms, after all.

The degree to which social conflicts are understood in human rights terms by the participants in these conflicts is, of course, an interesting empirical question. Furthermore, it is a question on which human rights scholarship and peace research can find common ground. If we think of human rights as a standard of justice, giving positive or negative sanction to existing social orders, it is easy to see how human rights can serve as focal points for political activity-sometimes in the form of rebellion or war (Sharp 1973; Forsythe 1993; Wood 2003; Skarstad 2015).

Historically, the idea of individual rights has generally been 'corrosive of existing structures of social power' (Reus-Smit 2013: 12). However, human rights concerns can obviously be both destabilizing and stabilizing, depending on the nature of the regime in question. On one hand, demands for rights can throw repressive political regimes into crisis 'when support among those subject to their rule collapses, forcing elites to engage in either [...] re-legitimation or coercion' (Reus-Smit 2013: 4). On the other hand, respect for human rights can be a source of unity. Threats to fundamental rights are one of the few things that can still get masses of people on the street in modern liberal democracies, in a common expression of support for their political system.

Although the role that human rights have played and continues to play in social struggles is partly an empirical question, it is also a question with a distinct normative dimension. Above all, human rights speak to the legitimacy of any particular social struggle. For instance, is a rebellion merely a disturbance of law and order - a matter 
for the police — or is it a justified attempt to bring about a better society? Note that this is not merely a matter of whether the participants themselves justify what they are doing by appealing to human rights — which is a purely empirical question — but also whether they are actually championing human rights, which is a conceptual and normative question. ${ }^{9}$ We can illustrate the normative and empirical axis in a $2 \times 2$ table:

\section{Empirical question}

\section{Are rebels appealing to human rights?}

Yes

No

Normative/ Are rebels actually Yes Justified rebellion Justified rebellion conceptual championing question human rights? No Unjustified rebellion Unjustified rebellion

Table I. the relation between the empirical and the normative dimension of investigating the role of human rights in social struggle.

The important lesson from table 1 is that treating the issue of human rights and social struggle purely as an empirical question does not allow us to distinguish between justified and unjustified rebellions. ${ }^{10}$ It is therefore no wonder that negative peace researchers, by insisting on treating the link between rights and peace as an empirical issue, tend to lump all upsetting of the social order indiscriminately into the same category of 'rebellion'. In a presidential address to this research community, Patrick M. Regan, raised the legitimacy issue as one of the things that peace research has struggled with: 
[i]t would be hard to put Mandela into the same category of a terrorist along with bin Laden, in part because most would agree that his cause was just. bin Laden, on the other hand, would probably generate little sympathy among those in the Peace Science community because his cause was certainly less just than Mandela's. [...]. [T] he difference-at least one of them-between Nelson Mandela and Osama bin Laden turns on our view of justice (Regan 2014: 354).

Is this a problem? One could argue that it is in fact a strength that peace researchers do not distinguish between Nelson Mandela and Osama bin Laden. After all, this distinction is irrelevant to the question of peace as long as peace is understood as merely the absence of violent conflict. After all, Mandela and bin Laden are equally threatening to negative peace - a threat that is quite independent of the justice of their cause. An analogy to the international level concerns just war (Walzer 2006), which is still war nonetheless, so why should we not try to prevent it?

However, the ambition to remove just war or just (armed) rebellion from the world is deeply paradoxical since saying that something is justified is the same as not objecting to it taking place. We land ourselves in a contradiction by saying "what Nelson Mandela did was justified, but he should have been stopped'. But, of course, saying 'what Nelson Mandela did was justified, but he should not have had to do it' is perfectly valid. Removing justified struggle from the world is not a matter of stopping the participants in such struggles from taking up arms, but a matter of removing the conditions that make such struggles justifiable in the first place, such as apartheid. A world where human rights are universally respected is possibly a world where conditions for justified rebellion are removed. We will get back to this point when we discuss positive peace in the next section. 
However, suppose that we are not concerned with the justifiability of a war or a rebellion, but only with negative peace, i.e. with stability. This would put certain uncomfortable options on the table in the interest of promoting (negative) peace. Jakobsen and de Soysa (2009: 153), for instance, find that human rights violations do not increase the risk of civil war and hence they argue that 'removing repression of empowerment rights should not be the main goal if one wants to reduce the risk of rebellion by ethnic groups' (Jakobsen \& de Soysa 2009: 153). In a similar manner, Mack observes that

[i]f Collier \& Hoeffler and Fearon \& Laitin are correct, and what counts is not grievance but the relative capabilities of rebels versus the state, then strategies of 'peace through strength', repression and deterrence would appear to be optimal prevention strategies (Mack 2002: 522).

We are not implying that negative peace researchers would endorse oppression in the name of peace. Jacobsen and de Soysa, for instance, immediately qualify their advice to not ease repression in the interest of maintaining stability with the observation that 'in the long run democracies are more stable' and that violating human rights is not 'normatively defensible' (Jacobsen \& de Soysa 2009: 153). Our main interest is the conceptual commitment to peace as stability that leads to repression being considered a possibility for maintaining peace in the first place. The logic can be condensed as follows:

(1) Justice is removed from the concept of peace, leaving stability as the only remaining component. 
(2) The relation between justice and peace-as-stability now emerges as an empirical question: is legitimacy an effective way of maintaining stability compared to repression?

The above reasoning (implicitly) puts stability over justice, in the sense that justice is investigated as a potential means for achieving stability. Putting stability over justice is in itself problematic from a human rights point of view. However, our concern is primarily that reducing peace to stability gets in the way of properly exploring complex relation between human rights and peace that we have previously outlined.

Negative peace research is, in effect, 'stability research', and human rights have an ambiguous relation to stability that is conditional on the nature of the established order. We can illustrate this fundamental point with reference to the constitutivenormative relationship between human rights and order we considered in section 2 . In the case of a human rights-based order-i.e. an order whose constitutional structure is grounded on human rights - human rights qua normative standard of justice provides political legitimacy and, as such, helps stabilize the existing order.

When confronted with an order that is not based on human rights, on the other hand, the normative relation between human rights and negative peace works in the exact opposite direction: by delegitimizing the established order, the idea of human rights becomes (potentially) a destabilizing force. (The constitutive relation, in such a case, would be potential rather than actual-manifesting itself as political project rather than a political reality).

Thus, if we want to think of peace as merely stability, the relation between human rights and peace will necessarily be unsettled and dependent on the political quality of the world we live in at any given moment. This important ambiguity creates 
a fundamental-but, we believe, largely unacknowledged-problem for negative peace researchers looking for a definitive answer to whether human rights lead to peace: their fundamental conceptual commitment to peace-as-stability makes such a definite answer impossible - it will all depend on the justice of the existing order.

This shortcoming of negative peace research is politically problematic insofar as means giving priority to stability over justice, which at least sometimes seems to be the implication. However, important human rights into a negative peace framework is also analytically problematic: merely adding human rights to the list of explanatory variables possibly correlated with stability does not do justice to the issue of human rights and peace. Of course, there is nothing inherently wrong with being concerned with stability — neither as a political interest nor as a research interest. But insofar as peace researches are serious about investigating the potential of human rights for creating and sustaining peace, they need an approach that can handle a vision of peace in which justice is an equal partner, and not a subordinate, to stability. Luckily, most of the basic components of which such an approach might be constructed are already present within the peace research tradition.

\section{Positive peace: peace and justice as a conceptual and normative question}

The negative concept of peace holds that justice and legitimacy are conceptually distinct from peace, making stability the essence of peace. In this section, we consider an alternative conceptualization of peace as a certain kind of order: a just order. This way of thinking, although not widespread in this research tradition at the moment, is not unfamiliar to peace research. Johan Galtung, one of the founding fathers of this research tradition, famously argued that peace did indeed concern the justice of society 
(Galtung 1969; 1985). For this reason, Galtung is usually considered a representative for a positive as opposed to the now-prevailing negative understanding of peace.

Positive peace (which is not synonymous with Galtung's particular understanding of peace) holds that peace, in the true sense of the word, entails a certain minimum integration of society that goes beyond repression. As such, a positive understanding of peace is more restrictive compared to the negative understanding of peace, replacing peace as stability with peace as a specific kind of order. Negative and positive peace are not mutually exclusive: a positive concept of peace rather adds a requirement beyond stability for calling something 'peace'. As such, positive peace is not the opposite of negative peace (which would be war), but a concretion of what the opposite of war actually is (Galtung 1969: 168; see also subsection 4.2).

Our ambition remains to clear the way for dialogue between human rights scholarship and peace research - a job that begins in earnest in this section. This section consists of three sub-sections that deal with different hurdles to such dialogue. The first subsection (4.1) is a meta-inquiry into the background conditions for asking the question 'what is peace?'. We suspect that much human rights scholarship and peace research resides in different paradigms of social inquiry, and the first step to conceptualizing peace is to clarify what the criteria for a good conceptualization are. After having established these criteria, the second and third subsections (4.2 and 4.3) examines more concretely the possibility of a human rights based understanding of peace. 


\subsection{The criteria for evaluating the concept of 'peace'}

At some point, positive peace got a bad reputation in the peace research community as vague, all-encompassing and empirically intractable. Indeed, the entire concept became, quite literally, a joke, as a senior figure in this community recalls:

[a] joke going around peace research circles at the time was that 'peace' was a bit like 'Paradise' in Christianity, a nice place - but it's not obvious what you do there expect float around in white garments (Gleditsch et al. 2014: 149).

Two concerns played an important role in the move from positive to negative peace within peace research: empirical measurability and value neutrality.

It is not difficult to imagine how the need for empirical operationalization facilitated the understanding of peace as merely absence of armed conflict. Although establishing whether an armed conflict is present is not without its own challenges, it provides in most cases a fairly undisputable metric. ${ }^{11}$ However, lack of empirical specificity was not the only problem with positive peace. Just as problematic was the inescapable normative and political aspect of including justice in the definition of peace.

In a seminal article, Kenneth Boulding argued that 'Galtung's thought is heavily normative, to the point perhaps where the description of reality suffers'. Boulding considered this a problem since "the scientist should be a rather cold fish and [...] emotions and affects should be reserved for those who do not hold the scientific ethic' (Boulding 1977: 77). Positive peace, it seemed to Boulding simply meant 'any state of affairs that get high marks on [Galtung's] scale of goodness' (Boulding 1977: 78). In 
the same vein, Rudolph Rummel dismissed Galtung's peace concept as ideology: as a ‘socialist theory of peace' (Rummel 1981: 83).

One notable trait of the criteria on the basis of which a positive concept of peace was rejected, i.e. empirical measurability and value neutrality, is that they are not really concerned with what peace is. To say that a particular concept lacks empirical measurability or that it is ideological is not the same as saying that it does not adequately capture what it is supposed to capture. It would obviously be absurd to argue that peace $i s$ that which is easy to measure empirically or that peace is value neutral. ${ }^{12}$ Despite these prima facie shortcomings, empirical measurability and value neutrality largely continue to set the premises for conceptual debates within peace research to this day.

However, in his Presidential address to the peace research community, Regan makes the case that values do not merely influence why we study peace (although, of course, that too). He also argues that '[h]ow we develop categories and who or what we put in them can reflect our values' (Regan 2014: 353). Yet, even if Regan concedes that definitions are not entirely value neutral—and that they do not have to be —-he still treats the definition of peace as primarily an issue of finding an 'operationally tractable definition' (Regan 2014: 350), i.e. as an issue of empirical operationalization.

We are now touching on an underlying obstacle to dialogue between human rights scholarship and peace research. Human rights scholarship evolved from philosophy into an interdisciplinary approach that spans law, humanities and social science (Freeman 2011). Peace research, on the other hand, is a more clear-cut social science tradition. This difference can create certain translation problems (for a more 
general discussion of this issue see Freeman 2001). One of the challenges is that social-scientific approaches tend to have a very pragmatic attitude to conceptual problems: 'rather than make sweeping claims about what the $[\ldots]$ concept [e.g. 'peace'] 'really' means, scholars should present specific arguments, linked to the goals and context of their research, that justify their particular choices' (Adcock \& Collier 2001: 532).

Such conceptual pragmatism finds epistemological justification in various versions of empiricism - arguably the dominant family of epistemologies in social science (Jackson 2011) — that do not really acknowledge 'conceptual knowledge' in itself as knowledge. A concept, on this understanding, is merely a tool for a subsequent empirical investigation, which is that produces actual knowledge as concepts are wedded to observation. Gary Goertz's Social Science Concepts (2006) contains one of the most explicit formulations of this position:

[if] the concept is not intimately related to the empirical analysis of a phenomenon, then there is nothing to which one can anchor the concept and everything becomes just a matter of who is in charge of the definition (Goertz 2006: 4).

On this understanding, the main concern is to tie, for instance, the concept of peace to an empirically observable state of affairs in order to give it meaning. Only when we can empirically observe peace does a science of peace become possible-we cannot actually know anything about peace until we can observe it. As such, it is best not to dwell too long on the conceptual discussion of what peace is, or else one risks the fate of the 'lilliputian scholars' who 'get so bogged down in definition that they never get 
to the inquiry itself' (Vasquez 1993: 14). The implication, of course, is that asking about the essence of peace as something accessible to reason, as philosophers have traditionally done, is misguided.

However, this empiricist attitude is paradoxical: before peace researchers can measure peace and explain how peace came about (and turn this information into the service of peace), peace must already be a reality. If it is not, we cannot possibly make empirical observations of peace in the first place; the concept of peace would be empty and peace research would never get off the ground as a science. It is at this point that philosophy objects: if peace is primarily an ideal and only potentially an empirical state of affairs, then we can know what peace is - even if the ideal does not (yet) correspond to empirical reality. For instance, Kant theorized about international peace without having much hope of ever empirically observing such a peace, which he considered merely a distant possibility in his own time:

[n]owhere does human nature appear less lovable than in the relations entire peoples have to each other. No state is for a moment secure from others in either its independence or its property. [...]. Now, the only possible remedy for this is a right of nations [...] for an enduring universal peace by means of the so-called balance-of-power in Europe is a mere fantasy (Kant 1996a: 309, emphasis removed).

Some observers have called contemporary European politics 'Kantian' in the sense that since the last World War, despite much conflict, disputes between European powers are now settled according to a principle of nonviolence (Wendt 1999: 294). If this is true, then empirical reality has moved closer to Kant's (positive) concept of peace. However, even if Kant's theory of peace corresponds more closely to (a part of) 
empirical reality today than in it did in 1793-this in itself does not make his understanding of peace any more correct or wrong than it was in 1793. If Kant said anything worthwhile about what peace is, it was equally valid regardless of the empirical circumstances that happened to prevail when he said it.

Obviously, a concept of peace is, on one level, a device for performing empirical measurements. However, the concept's validity as an adequate conceptualization of what we mean by 'peace' is not reducible to its function as an empirical measuring device. ${ }^{13}$ In our opinion, peace research needs to (re-)ask the question 'what is peace?' for its own sake. In the next two subsections, we consider how such an inquiry (re)opens a possible conceptual connection between human rights and peace.

\subsection{Reopening the question 'what is peace?' and reconsidering the role of human rights}

So far, we have argued that including human rights in peace research mandates a rethinking of the concept of peace. Such a rethink could potentially build on an already-present internal movement in this research tradition. Although conceptual battles are rare within peace research these days, some limitations of the paradigm of contemporary peace research are becoming visible. However, these problems are perhaps not yet recognized as the fundamental issues that they really are.

Regan concludes in his presidential address that after 50 years of peace research, 'we know remarkably little about peace' (Regan 2014: 350) —a failing he largely attributes to conceptually difficulties in pinning down exactly what peace is. A similar concern has motivated recent developments to rehabilitate a broader understanding of peace as more than simply 'not war': 
[t]raditionally, peace is conceptualized as the opposite of war; that is, peace is defined as the absence of war or armed conflict. This is a "negative" way to define and conceptualize peace. This is inadequate, however, if the goal of research is to understand and explain peace. If we want to explain why some people are "wealthy", it is not useful to define them as being "not poor" (Klein et al. 2008: 67).

We are sympathetic to this line of thinking, and we hope to encourage and contribute to it. In this final part of the essay, we move from the negative to the positive aspect of our critique, and attempt to indicate how human rights theory can add to our understanding of peace. We say 'indicate', because we cannot do full justice to this question here. Our ambition is more modest and connected to the overall purpose of the paper: to prepare the ground for dialogue, and even perhaps potential synthesis, between human rights theory and peace research.

The first step in such a dialogue is to re-ask the question 'what is peace?'. Even if it is inadequate as a final answer, the truism that peace is not war gives us a place to start. The next step is to give some content to what war is. The first thing we want to do is challenge the notion that war is simply armed conflict. Not to say that armed clashes is not a common component of war, but such clashes might not in themselves constitute war; as Thomas Hobbes noted 'the nature of War, consisteth not in actual fighting; but in the known disposition thereto' (Hobbes 1969: 56). Indeed, a war, as we learned in the previous century, need not necessarily find its expression in actual fighting between the adversaries - it can also be a cold war.

We can, of course, keep using the term 'war' to signify actual fighting, but then we should also, in the spirit of Klein et al. (2008), think of peace in broader terms than 
'not war'. For instance, the post-colonial African Peace was once described as a 'formal absence of international wars precariously maintained on an unstable basis by threats, deterrence, and/or a lack of will or capability to enter into interstate hostilities' (Kacowicz 1997: 367). On Hobbes' account this would not be peace at all, but actually a state of war.

However, regardless of what we call it, the important point is that there is an important distinction to be made between a 'peace' that is really an uneasy truce and a condition where 'war is unthinkable' (Klein et al. 2008: 67). Call the kind of non-war described by Kacowicz-where armed conflict is always on the table-'Hobbesian peace' and the kind of non-war where armed conflict is unthinkable 'Kantian peace'. This division is reflected in the Peace Scale, developed by (Klein et al. 2008):

[f]or example, the France-Germany and the Egypt-Israel rivalries were both particularly severe and extended over broad periods of time. The militarized aspects of their relationship have effectively ended, yet the state of relations in these two dyads is notably different. France and Germany are now in a condition of [Kantian] peace. [...]. Israel and Egypt are in a condition of [Hobbesian] peace. The two have not engaged in militarized dispute since 1989, yet the relationship is "cool" (Klein et al. 2008: 68).

The most important task for peace research is to find out how to move from (or avoid sliding into) a Hobbesian condition, where war is on the table, to a Kantian condition, where war is off the table. Having identified this primary challenge, we can now inquire (briefly) into the role of human rights, legitimacy and justice in this process. 


\subsection{Peace and human rights as a social contract -a sketch}

If the condition of possibility for peace is a fundamental consensus that removes the causes for war, then the real question we need to ask about human rights and peace is what role human rights can play (and potentially have played) with regards to establishing such consensus. By 'fundamental consensus' we are referring to something like a constitutional social contract. ${ }^{14}$ Thinking of peace in these terms is already well-established within peace research by those seeking to go beyond the 'greed and grievances' model of social conflict:

[t]he greed versus grievance dichotomy is a useful entry point into the debate. But for these forces to take the form of large scale violence, there must be other factors at work, specifically a weakening of the social contract (Murshed 2002: 390).

Murshed's point is that greed and grievances do not have to translate into violence if a viable social contract is in place. This way of thinking re-introduces positive content to peace in the sense of being concerned with the fundamental integration of human society' (Galtung 1964: 2). A disintegrated society is at best Hobbesian 'peace' where opportunistic behaviour at any time can take on violent form - at worst it is war in the form of actual fighting. Thus, on this line of thinking, establishing a working social contract and avoiding a degradation of this contract is the key component for establishing and sustaining peace.

Interestingly, peace agreements often do take on a constitutional form akin to a social contract—and they almost always include concerns for basic human rights: 
[w]hen a peace agreement is reached, often human rights provisions form a central part of its text. [...]. They are characterized by a constitutionalism designed to define, protect, and enforce rights, and to replace the arbitrary use of power with its legal regulation [...]. Where the conflict involves a self-determination claim by ethno-national groups [...] peace agreements also typically attempt to redefine state structures and the access of these groups to power. This is then coupled with the enforced protection of individual rights, aimed at creating a working polity out of a deeply divided society (Bell 2003: 1).

The role of human rights in such community-building processes agreements is by no means uncontroversial. ${ }^{15}$ Yet abstracting from practical difficulties we can still recognize that peace hinges on solving fundamental conflicts by way of establishing a constitutional structure and, as Bell puts it, 'a working polity'. Although it is possible to conceive of a Hobbesian 'polity' — for instance on the international level—sustained by hegemonic force or balance of power rather than consensus on basic political principles, this is not the kind of polity envisioned in human rights philosophy.

Rather, human rights philosophy sees peace as the constitutional integration of society (both national and international). Kant, for instance, explicitly connects peace to citiva - to being united under common law as opposed to existing in a lawless condition (Kant 1996b). John Locke, another pioneer of human rights thinking, likewise speaks of 'the state of war' as when "men are not under the ties of the common law' (Locke 2009: 76). For Kant, being in a civita is in itself a state of peace, meaning that the idea of a 'right to go to war is, strictly speaking, unintelligible' (Kant 1996b: 328) since the term 'right' only has meaning inside the fundamental union that would, in effect, be broken up by war (or more precisely: war is the break-up of union, the actual fighting being just a symptom of the underlying disintegration). 
Another way to put this is that the essence of war is the dissolution of community, and that building peace after war means reconstituting this community. Human rights are potentially important in this respect since '[v]iolation of human rights are not simply assaults on the persons and goods that these rights protect-but they are also violations of a respect that citizens owe to other citizens' (Philpott 2012: 176). The first victim of war, one could say, is the humanity of the enemy. And the first act of war is to draw a line of 'moral exclusion' (Opotow 1990) such that those on the outside are placed 'beyond our moral concerns, and eligible for deprivation, exploitation, and other harms that might be ignored or condoned as normal, inevitable and deserved' (Opotow et al. 2005: 305).

As such, a good argument can be made that peace must be universal in the sense of being grounded in a moral community that includes all human beings, since exclusion from moral community itself is an act of war (if we by 'war' mean disunion). The proclamation at the start of the Universal Declaration that 'all human beings are born free and equal in dignity and rights' and therefore should 'act towards each other in a spirit of brotherhood', could be read, from a peace-research perspective, as a vision of a certain kind of peace — not merely as something that might or might not be associated with peace.

Thus, even if it is legitimate to empirically question the feasibility of establishing a human rights-based peace in any particular instance, the very concept and possibility of a human rights-based peace is not an empirical claim awaiting to be tested so much as a political project awaiting to be realized. We now have considerable historical experience with this political project of creating working 
polities based on human rights - an experience that justifies both carefulness and confidence. Empirical peace research can potentially tell us a lot about when to be careful and when to be confident, but it can perform this task efficiently only after a preliminary conceptual reflection on how human rights and peace are connected-a reflective process to which we have hopefully have provided a small contribution.

\section{Conclusion}

In this essay, we have considered the challenge of including human rights in the study of peace. Our argument can be summarized in three points. First: treating the relation between human rights and peace as a straightforward empirical question — arguably the default approach in contemporary peace research — is more problematic than is usually acknowledged. Seeing this relation as a purely empirical question, we have argued, presupposes a decoupling of peace, justice and legitimacy on the conceptual level. In short, it separates peace from political community and reduces peace to a byword for stability-something that can potentially be achieved just as effectively through repression as through legitimacy. The orthodoxy of defining peace purely 'negatively' sets the stage for this unfortunate line of thinking in peace research.

Our second point is that seeing peace as a certain kind of order is an improvement on seeing peace as co-extensive with stability. For this purpose, we suggested a distinction between Hobbesian and Kantian peace. The former corresponds to a 'negative' definition of peace, while the latter corresponds to a (fairly minimalist) positive concept of peace where a working social contract has removed war as a legitimate means for resolving conflicts—which, in effect, also means that 
certain kinds of conflict pertaining to the fundamental constitutional framework for coexistence are settled.

The distinction between Hobbesian and Kantian peace is already recognized (by some) in mainstream peace research. Our main contribution on this point, is primarily to emphasize the full implications of moving to this more 'positive' way of thinking about peace-particularly as it relates to including human rights in peace research. Specifically, moving from a purely negative to a positive understanding of peace entails that the relation between human rights and peace is no longer a (purely) empirical question, but more fundamentally a conceptual issue. In other words, expanding the conception of peace has epistemological consequences for peace research that needs to be reflected into this research tradition.

The final point we have made is that if peace is a certain kind of social order, then the universal moral community envisioned by human rights theory and human rights law is a good candidate for such an order. As such, we applaud the ambition of a peace science that "does not run away from identifying a world where universal human rights, rights of women, freedom from poverty and the distinct lack of armed violence that goes with it" (Regan, 2014, 353). However, if peace researchers are serious about living up to this kind of rhetoric, they need to engage with human rights in a different manner than they have thus far. 


\section{References}

Adcock, Robert and David Collier (2001): "Measurement validity: A shared standard for qualitative and quantitative research", American Political Science Review, 95(3): 529546.

Addison, Tony and S Mansoob Murshed (2001): "From conflict to reconstruction: Reviving the social contract", WIDER Discussion Papers//World Institute for Development Economics (UNU-WIDER).

Anonymous (1996), 'Human Rights in Peace Negotiations', Human Rights Quarterly, $18(2), 249-58$.

Bailliet, Cecilia M (2014): "Normative Foundations of the International Law of Peace", in C. M. Bailliet and K. M. Larsen (Eds.) Promoting Peace Through International Law. Oxford: Oxford University Press.

Bailliet, Cecilia M and Kjetil Mujezinović Larsen (2013): "Nordic Expert Consultation on the Right to Peace: Summary and Recommendations", Nordic Journal of Human Rights, 31(2): 262-278.

Bell, Christine (2003): Peace agreements and human rights. Oxford: Oxford University Press.

Boulding, Kenneth E. (1977): "Twelve Friendly Quarrels with Johan Galtung", Journal of Peace Research, 14(1): 75-86.

Bull, Hedley (2002): The Anarchical Society: A Study of Order in World Politics. $4^{\text {th }}$ ed. New York: Columbia University Press.

Buzan, Barry (2014): An Introduction to the English School of International Relations: The Societal Approach. Cambridge: Polity press. 
Collier, Paul, Lani Elliot, Håvard Hegre, Anke Hoeffler, Marta Reynal-Querol and Nicholas Sambanis (2003): Breaking the Conflict Trap: Civil War and Developement Policy. World Bank Policy Research Report 56793.

Collier, Paul and Anke Hoeffler (2004): "Greed and grievance in civil war", Oxford economic papers, 56(4): 563-595.

Donnelly, Jack (2013): Universal human rights in theory and practice. Itacha: Cornell University Press.

Euben, Roxanne Leslie and Muhammad Qasim Zaman (2009): Princeton readings in Islamist thought: texts and contexts from al-Banna to Bin Laden. Princeton: Princeton University Press.

Evans, Matthew (2016), 'Structural violence, socioeconomic rights, and transformative justice', Journal of Human Rights, 15 (1), 1-20.

Fearon, James D and David D Laitin (2003): "Ethnicity, insurgency, and civil war", American political science review, 97(1): 75-90.

Forsythe, David P. (1993): Human Rights and Peace. International and National Dimensions. Madison: University of Nebraska Press.

Freeman, Michael (2001): “Is a Political Science of Human Rights Possible?”, Netherland Quarterly of Human Rights, 19(2): 123-139.

Freeman, Michael (2011): Human Rights: An Interdisciplinary Approach. Cambridge: Politi Press.

Galtung, Johan (1964): "An editorial", Journal of Peace Research, 1(1): 1-4.

Galtung, Johan (1969): "Violence, peace and peace research", Journal of peace research, 6(3): 167-191.

Galtung, Johan (1985): "Twenty-Five Years of Peace Research: Ten Challenges and Some Responses", Journal of Peace Research, 22(2): 141-158. 
Gates, Scott (2002). "Empirically assessing the causes of civil war". Paper presented at the 43rd Annual International Studies Association, New Orleans, LA.

Gleditsch, Nils Petter, Jonas Nordkvelle and Håvard Strand (2014): "Peace research-Just the study of war?", Journal of Peace Research, 51(2): 145-158.

Glendon, Mary Ann (2002): A world made new: Eleanor Roosevelt and the Universal Declaration of Human Rights. New York: Random House.

Goertz, Gary (2006): Social science concepts: A user's guide. Princeton: Princeton University Press.

Gready, Paul and Robins, Simon (2014), 'From transitional to transformative justice: a new agenda for practice', International Journal of Transitional Justice, 8 (3), $339-61$.

Henkin, Louis (1995), 'Human Rights and State Sovereignty', Ga. J. Int'l \& Comp. L., 25,31 .

Hobbes, Thomas (1969): Leviathan. Saarbrücken: Scolar Press.

Human Rights Council (2012). "Action on Resolution on the Promotion og the Right to Peace".

Jackson, Patrick T. (2011): The Conduct of Inquiry in International Relations: Philosophy of Science and its Implications for the Study of World Politics. London: Routledge.

Jakobsen, Tor G. and Indra de Soysa (2009): "Give Me Liberty, or Give Me Death! State Repression, Ethnic Grievance and Civil War, 1981-2004", Civil Wars, 11(2): 137157.

Kacowicz, Arie M (1997): " 'Negative' International Peace and Domestic Conflicts, West Africa, 1957-96", The Journal of Modern African Studies, 35(03): 367-385. 
Kant, Immanuel (1996a): "On the common saying: that may be correct in theory, but it is of no use in practice", in M. J. Gregor (Ed.) Practical philosophy. Cambridge: Cambridge University Press.

Kant, Immanuel (1996b): "Toward perpetual peace", in M. J. Gregor (Ed.) Practical philosophy. Cambridge: Cambridge University Press.

Klein, James P, Gary Goertz and Paul F Diehl (2008): "The peace scale: Conceptualizing and operationalizing non-rivalry and peace", Conflict Management and Peace Science, 25(1): 67-80.

Locke, John (2009): Two treaties of government. Kansas: Digireads.

Mack, Andrew (2002): "Civil war: Academic research and the policy community", Journal of Peace Research, 39(5): 515-525.

Mebane, Walter R. and Paul Poast (2013): "Causal Inference without Ignorability: Identification with Nonrandom Assignment and Missing Treatment Data", Political Analysis, 21(2): 233-251.

Millar, Gearoid and Lecy, Jesse (2016), 'Disciplinary Divides in Post-Conflict Justice and Peace: Tracking If and How we Share Ideas', Journal of Intervention and Statebuilding, 10 (3), 302-20.

Murshed, S. Mansoob (2002): "Conflict, Civil War and Underdevelopment: An Introduction", Journal of Peace Research, 39(4): 387-393.

Nickel, James W. (2007): Making Sense of Human Rights. Malden: Blackwell Publishing

Opotow, Susan (1990): "Moral Exclusion and Injustice: An Introduction", Journal of Social Issues, 46(1): 1-20.

Opotow, Susan, Janet Gerson and Sarah Woodside (2005): "From Moral Exclusion to Moral Inclusion: Theory for Teaching Peace", Theory Into Practice, 44(4): 303-318. 
Philpott, Daniel (2012): Just and unjust peace: An ethic of political reconciliation: Oxford University Press.

Rawls, John (2005): Political Liberalism. New York: Columbia University Press.

Regan, Patrick M (2014): "Bringing peace back in: Presidential address to the Peace Science Society, 2013", Conflict Management and Peace Science, 31(4): 345-356.

Reus-Smit, Christian (1997): 'The Constitutional Structure of International Society and the Nature of Fundamental Institutions', International Organization, 51(4): 555-89.

Reus-Smit, Christian (2011), 'Struggles for individual rights and the expansion of the international system', International Organization, 65 (02), 207-42.

Reus-Smit, Christian (2013): Individual Rights and the Making of the International System. Cambridge: Cambridge University Press.

Rost, Nicolas, Gerald Schneider and Johannes Kleibl (2009): "A global risk assessment model for civil wars", Social Science Research, 38(4): 921-933.

Rummel, Rudolph Joseph (1981): The Just Peace. London: Sage.

Sambanis, Nicholas (2002): "A review of recent advances and future directions in the quantitative literature on civil war", Defence and Peace Economics, 13(3): 215-243.

Schlunck, Angelika (1997): "Do human rights violations increase the risk of civil war?", ILSA J. Int'l \& Comp. L., 4(2): 415-422.

Seth, Sanjay (2013), 'Postcolonial Theory and the Critique of International Relations', pp. 1531 in Sanjay Seth (ed.) Postcolonial Theory and International Relations: A Critical Introduction. London: Routledge.

Sharp, Gene (1973): The Politics of Nonviolent Action. Manchester: Porter Sargent Publishers.

Siedentop, Larry (2014): Inventing the individual: The origins of Western liberalism. Boston: Harvard University Press. 
Simmons, Beth A. (2009): Mobilizing for Human Rights: International Law in Domestic Politics. Cambridge: Cambridge University Press.

Skarstad, Kjersti (2015): "Human Rights Violations and Conflict Risk - a theoretical and empirical assessment", in C. M. Bailliet and K. M. Larsen (Eds.) Promoting Peace Through International Law. Oxford: Oxford University Press.

Skarstad, Kjersti and Håvard Strand (2016): "Do human rights violations increase the risk of civil war?", International Area Studies Review, 19(2): 107-130.

Steiner, Henry J., Philip Alston and Ryan Goodman (2008): International Human Rights in Context: Law, Politics, Morals: Text and Materials. Oxford: Oxford University Press.

The United Nations Office at Geneva, UNOG (2012). "Human Rights Council establishes working group to negotiate a draft declaration on the right to peace." from http://www.unog.ch/80256EDD006B9C2E/(httpNewsByYear_en)/741DF607AF802B AAC1257A320053916E?OpenDocument.

Themnér, Lotta and Peter Wallensteen (2012): "Armed Conflicts, 1946-2011", Journal of Peace Research, 49(4): 565-575.

Thoms, Oskar NT and James Ron (2007a): "Do Human Rights Violations Cause Internal Conflict?", Human Rights Quarterly, 29(3): 674-705.

Thoms, Oskar NT and James Ron (2007b): "Do human rights violations cause internal conflict?", Human Rights Quarterly: 674-705.

Tuck, Richard (1999): The Rights of War and Peace: Political Thought and the International Order from Grotius to Kant. Oxford: Oxford University Press.

UN General Assembly (1948): "Universal Declaration of Human Rights". U.N. Doc A/810 at $71(1948)$.

Vasquez, John A (1993): The War Puzzle. Cambridge: Cambridge University Press. 
Walzer, Michael (2006): Just and unjust wars: A moral argument with historical illustrations.

New York: Basic Books.

Wendt, Alexander (1999): Social Theory of International Politics. Cambridge: Cambridge University Press.

Wood, Elisabeth Jean (2003): Insurgent collective action and civil war in El Salvador. Cambridge: Cambridge University Press.

Østby, Gudrun (2013): "Inequality and political violence: A review of the literature", International Area Studies Review, 16(2): 206-231.

\footnotetext{
${ }^{1}$ See also the UN Secretary-General's (1992: para. 5) claim that ' $[t]$ he sources of conflict and war are pervasive and deep. To reach them will require our utmost effort to enhance respect for human rights and fundamental freedoms'. In addition, the relation between human rights and peace is explicitly stated in article 55 of the Charter of the United Nations (United Nations 1945): "With a view to the creation of conditions of stability and well-being which are necessary for peaceful and friendly relations among nations based on respect for the principle of equal rights and self-determination of peoples, the United Nations shall promote: [...] universal respect for, and observance of, human rights'. The interdependency of human rights and peace has also been reiterated in Security Council resolution 1674 (UN Security Council 2006).

${ }^{2}$ By "peace research" we generally refer to the scientific study of peace centred on journals such as Journal of Conflict Resolution, Journal of Peace Research and Conflict Management and Peace Science.

${ }^{3}$ Peace researchers have traditionally not considered human rights causally relevant to peace due to lack of empirical support (see e.g. Collier et al. 2003; Fearon \& Laitin 2003). However, recently researchers have found some empirical backing for the view that injustices and
} 
inequality, which at least indirectly can be linked to lack of human rights protection, can increase the risk of a conflict outbreak (Østby 2013). A few notable studies have looked at the effects of human rights directly (Thoms \& Ron 2007; Jakobsen \& De Soysa 2009; Skarstad \& Strand 2016), with mixed results.

${ }^{4}$ The European countries were sceptical to the draft due to 'deep conceptual flaws of the alleged "right to peace" (Human Rights Council 2012), and the United States was against the declaration as a whole because it 'would cover many issues that are, at best, unrelated to the cause of peace' (The United Nations Office at Geneva 2012; Balliet 2014).

${ }^{5}$ Of these three points, only (1) and (2) are argued for at length. Claim (3) is rather 'sketched' in the final section as a natural continuation of the argumentative thrust in the essay. Our ambition is not to provide a full-blown social contract theory of peace in this essay, but rather argue its desirability and, importantly, to show how such a transition would not only be a conceptual transition, but a political-normative and epistemological transition as well.

${ }^{6}$ We put 'negatively' in quotation marks to indicate that we do not really believe that any definition of peace is purely negative. A definition of peace is also a specification of an ideal, and as such it has positive content, i.e. it provides a positive contrast to states of affairs that are not peace (see below).

7 "What is peacebuilding?", United Nations Peacebuilding Fund. URL: http://www.unpbf.org/application-guidelines/what-is-peacebuilding/ [accessed January 4, 2017]

${ }^{8}$ However, the reader should note that the empirical question of whether and to what degree human rights currently function as a universal standard of justice regulating international as well as domestic political life in many parts of the world is, strictly speaking, secondary to our argument. We premise this essay on a particular understanding of what the concept of human rights is - a standard of justice - and investigate what, as a standard of justice, it can potentially do in terms of creating and sustaining peace, and the (surprisingly fundamental) implications this has for a peace research serious about human rights. Obviously, if the 'peace potential' of human rights is to be not only investigated but realized politically, the two caveats mentioned above will be significant challenges.

${ }^{9}$ For the sake of the simplicity, we do not discuss whether violent rebellion as a method in itself ever can be justified (there are indeed strong reasons, from a human rights perspective, that it may not be).

${ }^{10}$ This generalizes to all standards of justice, not just human rights.

11 The conceptual discussion among peace researchers today has largely turned into a somewhat technical debate concerning, for example, how many battle-deaths make a war (e.g. Gates 2002; Sambanis 2002).

${ }^{12}$ Indeed, the latter is obviously not true since peace is most certainly a value, i.e. something to strive for and realize. After all, there is a reason we spend public funds on things like peace research in the first place.

13 The same, of course, is true for human rights as they are specified in the Universal Declaration and proceeding international human rights conventions. The human rights stated in such documents were never meant to describe any de facto situation in any state. These conventions are a plea to move towards an ideal situation, where fundamental rights are fully respected. As such both human rights and peace are ideals to strive towards, and as normative signposts their contents are crucial to discuss and clarify. Empirical research is important in terms of establishing how current conditions measure up to these ideals, but it cannot replace the ideals themselves. 
14 The way we use the term 'social contract' here-as a fundamental consensus on basic rules - is somewhat loose in order to capture a state of affairs that may apply both to the national as well as the international level.

${ }^{15}$ In a famous comment on the inclusion of human rights concerns in the former Yugoslavian peace process in the mid-1990s, an anonymous researcher concluded that '[t]housands of people are dead who should have been alive-because moralists were in quest of the perfect peace' (Anonymous, 1996: 258). 